\title{
Vulnerability assessment of water resources in Egypt to climatic change in the Nile Basin
}

\author{
Kenneth M. Strzepek ${ }^{1}$, David N. Yates ${ }^{1}$, Dia El Din El Quosy ${ }^{2}$ \\ ${ }^{1}$ Strzepek \& Associates, 5343 Aztec Drive, Boulder, Colorado 80303, USA \\ ${ }^{2}$ Water Management Research Institute, Water Research Center, Cairo, Egypt
}

\begin{abstract}
The impacts of global climate change on the water resources of the Nile River Basin were evaluated using simulation models. Four climate change scenarios were evaluated (baseline, GISS, GFDL, and UKMO). The complete impact of climatic changes in the Nile cannot be fully predicted with confidence, as some models forecast increased flows, while others project significant decreases. However, it was observed that the Nile River flow is extremely sensitive to ambient temperature and precipitation changes, and it is possible that the effects of climatic fluctuations would be severe. Several water management options were identified to help adapt Nile River management to a changing global climate.
\end{abstract}

KEY WORDS: Climate change $\cdot$ Egypt $\cdot$ Nile $\cdot$ Potential adjustments Water balance model(s) - Water resources

\section{INTRODUCTION}

Egypt relies heavily upon the Nile River, which forms more than $95 \%$ of the national water budget (Shahin 1985). Very small quantities of precipitation fall near the Mediterranean Sea, and the intensity of the rain varies spatially and temporally. Some groundwater also exists in Egypt, such as shallow aquifers associated with irrigation in the Nile Valley and Delta. Other shallow reservoirs are found in the coastal strip as freshwater lenses occurring above saline groundwater. Deep groundwater can be found in the Western Desert, Eastern Desert, and Sinai Peninsula, but these aquifers contain geologic supplies that will not be renewed after abstraction.

The Nile Basin covers roughly 2.9 million $\mathrm{km}^{2}$, which is almost one-tenth the area of Africa (Gleick 1991). The river flows north for a distance of $6500 \mathrm{~km}$ from $4^{\circ} \mathrm{S}$ to $31^{\circ} \mathrm{N}$ latitude, and extends from $21^{\circ} 30^{\prime}$ to $40^{\circ} 30^{\prime} \mathrm{E}$ longitude. The Nile and its tributaries (White Nile, Blue Nile) flow through Tanzania, Uganda, Rwanda, Burundi, Zaire, Kenya, Ethiopia, Sudan, and Egypt (Shahin 1985). Although the Nile watershed is large, the portion contributing to streamflow is only about 1.6 million $\mathrm{km}^{2}$, ending near the confluence of the Atbara River and the Nile. North of $18^{\circ} \mathrm{N}$, precipi- tation is insignificant. The specific discharge of the Nile (long-term average annual flow divided by the area of the watershed) is the lowest for all river basins with areas greater than 1 million $\mathrm{km}^{2}$. Even if the noncontributing portion is removed, the Nile's specific discharge is about the same as the Missouri River in the USA, which has the second lowest specific discharge. The Congo River Basin, which shares a long common watershed divide with the Nile, has approximately 10 times the specific discharge of the Nile (Kalinin 1971, cited in Shahin 1985).

This contrast in the Nile and Congo river basins can be explained by climate and topography (Shahin 1985). The Nile's hydrologic characteristics are extraordinarily sensitive to climate change. The Nile is marked by 2 topographic extremes: mountainous plateaus and flat plains. The Equatorial Plateau and its system of lakes have a very delicate water balance, with direct evaporation from the lake surfaces almost equal to the direct precipitation onto the lakes. Although the net water gain per unit area is small, the area of the lakes is large, so the direct lake water supply plus the tributary inflow results in a large supply of water. However, a small shift in either rainfall or evaporation can result in dramatic changes in Lake Victoria, as observed in the 1960s when an historically rapid rise 
and increase in lake discharge occurred. Piper et al. (1986) observed that the 1961-1964 rise is not unique and that similar fluctuations have occurred in the past. Indeed there is some evidence from paleoclimatic records that in recent times the Victoria Basin became closed with no outflow.

Gleick (1992) evaluated the vulnerability of runoff in the Nile Basin to climatic changes. Evaluating runoff estimates of 3 General Circulation Models (GCMs) for the Blue Nile region revealed mixed conclusions: runoff increases in 2 of the scenarios and decreases in the third. Gleick (1992) concluded that future climatic changes in the Nile Basin cannot yet be predicted with confidence, but there are indications that any changes would be significant and possibly severe. Current and future precipitation changes of the Nile Basin were studied by Hulme (1992). During the period 1880 to 1989, the upper White Nile catchment, the upper Blue Nile catchment, and the Middle Nile showed a decline in total precipitation. A GCM scenario analysis for 1861 to 1988 showed overall warming of about $0.5^{\circ} \mathrm{C}$.

Future climate of the Mediterranean Basin with particular emphasis on changes in precipitation was considered by Wigley (1993). The most likely future scenario for the Mediterranean Basin is a warming of about $3.5^{\circ} \mathrm{C}$ over the basin, spread uniformly over the seasons. Most of the basin shows an increase in precipitation in winter. In Egypt and Israel, the probability of a precipitation decrease in spring exceeds 0.7 . The projected change in precipitation between now and 2050 is about $+1 \mathrm{~mm} \mathrm{~d}^{-1}$. An increase in precipitation to the Nile headwaters is projected, with consequences for Egypt.

Climate change and water resources in the Nile Basin were also evaluated by Conway \& Hulme (1993). Three GCM scenarios implied changes in mean annual runoff due to a $1^{\circ} \mathrm{C}$ temperature increase of $-0.2,-4.2$, and +12.2 billion cubic meters (BCM). Conway \& Hulme (1993) concluded that the effects of future climate change on Nile discharge will further increase the uncertainties in Nile water planning and management, especially in Egypt. Moreover, there is no correlation in either precipitation or runoff between the White Nile and Blue Nile regions. Blue Nile runoff is moderately well correlated to Sahelian precipitation. While Nile precipitation responds more to changes in Equatorial circulation, it is little influenced by the North African monsoon (Sestini 1993).

The objectives of this report are to (1) model impacts of future global climate change on Nile River water flow, and (2) identify potential adaptation options for Nile Basin management in response to climate change.

\section{MATERIALS AND METHODS}

Modelling impacts of climate change on flow. This study took a water balance approach similar to that of Gleick (1987) in modelling the impacts of climate change on Nile flows. The basin was divided into 5 major components: the Equatorial Lakes Basin, the Sudd Basin, the Blue Nile Basin, the Atbara Basin, and losses along the White and Main Nile Basins (Fig. 1). The Equatorial Basin was divided into 4 catchment areas and 3 lakes, each modelled separately. The Sudd Basin is a simplified representation of the entire White Nile catchment from Mongalla to Malakal, including the Sobat River. All the swamps were represented as one and modelled via the water balance method described by Sutcliffe \& Parks (1987).

Modelling the catchments. All the catchments were modelled in a lumped, 1-dimensional water balance model with spatially weighted parameters (Fig. 2). The model used a geographic information system (GIS) to determine precipitation and temperature surfaces of monthly average values on a $25 \times 25 \mathrm{~km}^{2}$ grid for the entire basin. Catchment boundaries were delimited on these surfaces and the weighted average monthly values of precipitation and temperature were calculated for each of the 4 major catchment areas.

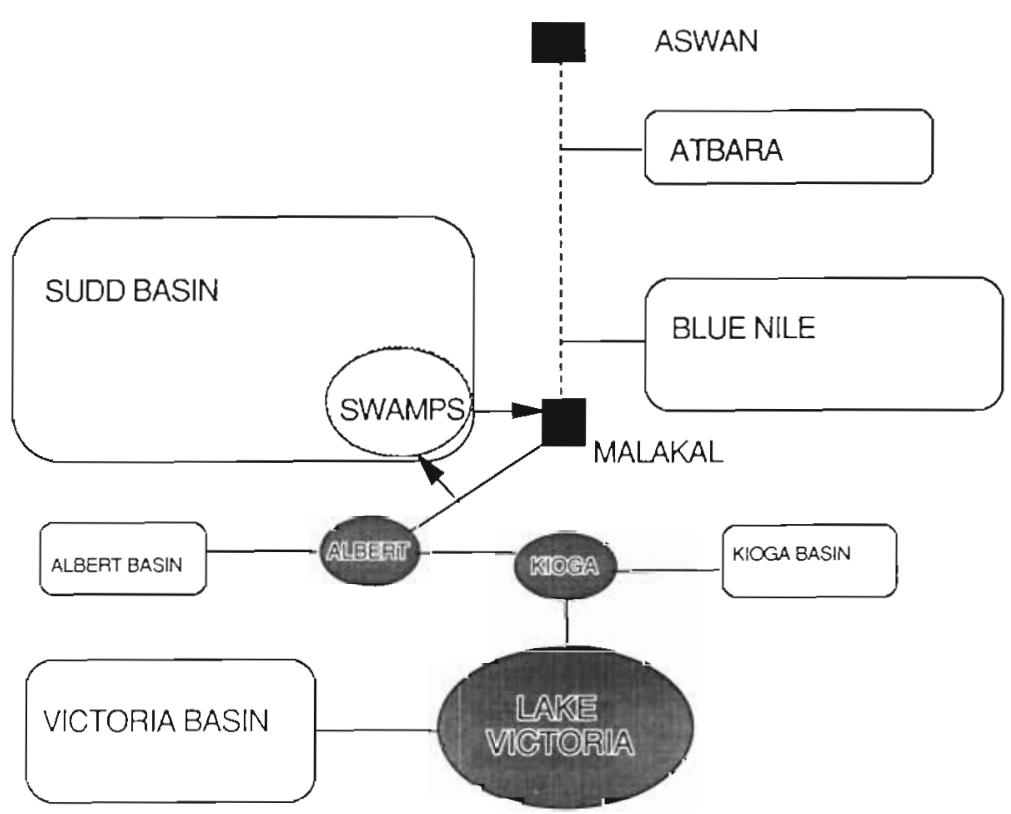

Fig. 1. Schematic diagram of Nile River basin water balance model 


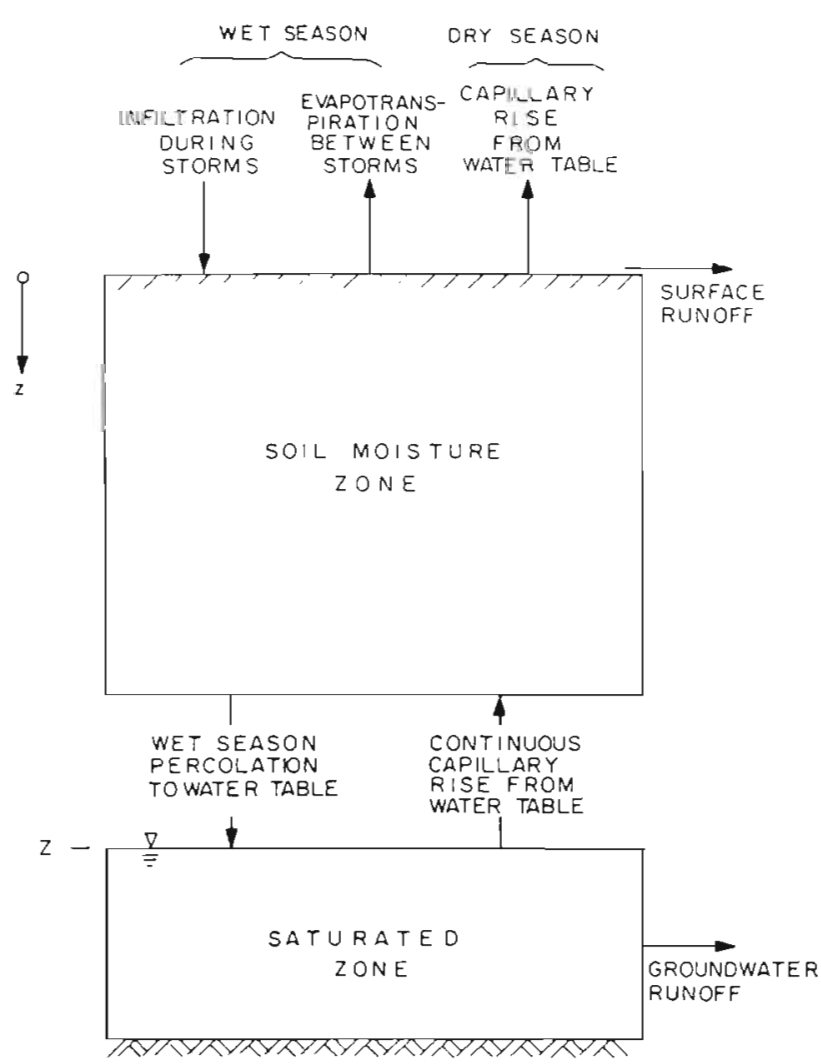

SCHEMATIC REPRESENTATION OF SOIL COLUMN

Fig. 2. Schematic diagram of soil moisture and groundwater zone model

The average monthly precipitation values were used directly in the model, but temperature was used to derive average monthly PET (potential evapotranspiration) using the Thornthwaite method (Shaw 1987). Thornthwaite was chosen because Oliver (1969) successfully used the Thornthwaite approach to study PET in the Nile basin, and his work is well regarded.

The soil moisture and groundwater zones were modelled by separate water balance models with exchanges between them (Fig. 2). Input to soil moisture was the balance of water remaining after interception losses and direct surface runoff. Direct surface runoff was a linear function of the soil moisture. The groundwater component of runoff was modelled as a nonlinear function of storage in the groundwater zone.

With precipitation data available and PET determined, the model was calibrated by fitting 4 parameters: surface runoff coefficient, interception coefficient, and $a$ and $b$ in the non-linear groundwater runoff equation. For most basins, these parameters were constant over the year. However, for 2 of the basins, wet season and dry season parameters were needed.

The Equatorial Lakes were modelled using a monthly mass-balance approach with catchment inflow, direct lake precipitation, and lake evaporation equal to PET. The model used the lake's elevationarea-storage curves and non-linear outflow-storage curves (WMO 1977). No calibration was computed for the lakes.

The swamps of the Sudd were modelled using the mass-balance and non-linear reservoir approach of Sutcliffe \& Parks (1987). Inflow to the swamps was the catchment runoff plus the spill from the Bahr al Jabal. The contribution to the White Nile flow at Malakal from the Sudd was the discharge from the swamps.

The model results using historical precipitation and temperature data from 1900 to 1972 revealed that total mass-balance is within $3 \%$ of measured data and the general shape of the hydrograph is correct. The model results for this historical climate provide the base scenario in the climate change analyses.

Modelling climate change using GCMs and sensitivity analyses. Climate change was simulated with GCM scenarios and sensitivity analyses for changes in temperature and precipitation (Unganai 1996, this issue). To assess climate change effects, the GCM grids were overlaid on the historic monthly temperature and precipitation surfaces in the GIS. The change in temperature between the $1 \times$ and $2 \times \mathrm{CO}_{2}$ scenarios for each grid cell was considered constant over the cell and was added to the historic value to produce a new temperature surface for that month. The precipitation change (as a ratio of climate change to base values) was overlaid on the historic precipitation surface and then multiplied to produce a new precipitation surface. This procedure was carried out for all months for the 3 GCMs. The GCMs employed in the analysis include: Goddard Institute for Space Studies (GISS) (Hansen et al. 1983); Geophysical Fluid Dynamic Laboratory (GFDL) (Manabe \& Wetherald 1987); and the United Kingdom Meteorological Office (UKMO) (Mitchell et al. 1989). The baseline scenario was current climate (Gleick 1991) and modelling was completed using methods described by Gleick (1987). Catchment weighted-average climate parameters were calculated from the new temperature and precipitation surfaces. For the sensitivity analyses, spatially homogeneous changes in temperature $\left(+2\right.$ and $\left.+4^{\circ} \mathrm{C}\right)$ and precipitation $( \pm 20 \%)$ were applied to the reference climate parameters.

\section{RESULTS}

\section{Water balance impacts}

The impacts of global climate change on Nile River flows at Aswan, based on 3 GCM scenarios, are presented in Tables $1 \& 2$ and in Fig. 3, respectively. The 
Table 1. Nile River flows under GCM scenarios

\begin{tabular}{|c|c|c|c|c|}
\hline & Base & UKMO & GISS & GFDL \\
\hline Precipitation ${ }^{\mathrm{d}}$ & 100 & 122 & 131 & 105 \\
\hline Temperature $^{b}$ & 0 & 4.73 & 3.45 & 3.15 \\
\hline Flow (MCM) & 86 & 76 & 1.12 & 20 \\
\hline$\%$ of base & 100 & 88 & 130 & 23 \\
\hline
\end{tabular}

sensitivity analyses indicated that the Nile Basin is extremely sensitive to any change in climate. Under one scenario, with $4{ }^{\circ} \mathrm{C}$ warming and a $20 \%$ decrease in precipitation, Nile River flow decreases $98 \%$. This represents a significant reduction in water supply. The other sensitivity tests indicated that the response of the Nile basin to precipitation change is not linear, but is symmetric for both increased and decreased precipitation.

The GCM scenario analyses revealed a range of results for the water balance of Sudan and Egypt. Four significant climate change impacts emerged:

(1) The Equatorial Lakes have a very delicate water balance, and even a slight increase in temperature or slight decrease in precipitation in the Lakes' sub-basin forces their contribution to the Nile flow to zero. The 15 and $17 \%$ increases in precipitation and 2.7 and $4.8^{\circ} \mathrm{C}$ warming for the GFDL and UKMO models, respectively, cause the Equatorial Plateau to provide almost no water to the Nile system. The GISS scenario, with a $38 \%$ increase in precipitation and $3.6^{\circ} \mathrm{C}$ warming, contributed only an amount of water equal to the historic yield. Thus, the runoff increase from a $38 \%$ increase in precipitation is almost completely offset by the runoff decrease resulting from a $3.6^{\circ} \mathrm{C}$ increase in temperature.

(2) The Sudd, currently responsible for high water loss, would have increased evapotranspiration due to increases in temperature (Table 3 ). In addition, with less spillage from the Equatorial Lakes, the Sudd would evapotranspire more runoff from the Sudd catchment, counterbalancing the 20,24 , and $2 \%$ precipitation increases under the UKMO, GISS, and GFDL scenarios.

(3) The Ethiopian Highlands are the key to Nile flows under historic climate as well as under possible climate change. Under the UKMO scenario, with the White Nile contributing no flow, total Nile flow is reduced by only $12 \%$ (Fig 3 ). Loss of the $27 \mathrm{MCM}$ (million cubic meters) of the White Nile is made up by the $14 \%$ yield increase of the Blue Nile

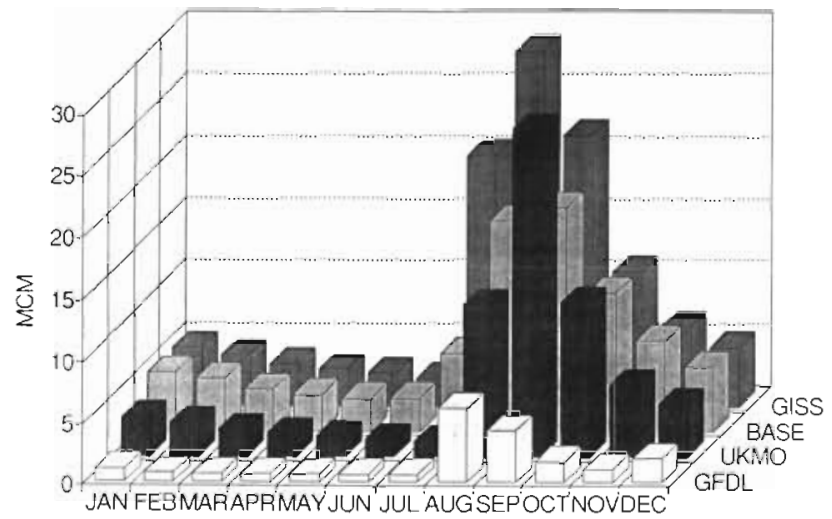

Fig. 3. Simulated impact of 3 GCM scenarios (GFDL, UKMO GISS) on Nile River basin flow compared to baseline (current) climate conditions

and $67 \%$ increase of the Atbara River. This is possible even with greater than $4^{\circ} \mathrm{C}$ warming in both basins, given the 32 and $53 \%$ increases in precipitation in the Blue and Atbara Basins, respectively. Similar conditions prevail under the GISS scenario, with 35 and $48 \%$ increases in precipitation for the Blue and Atbara Basins, but with smaller annual temperature increases of only $3.2^{\circ} \mathrm{C}$ in both basins. This scenario results in a $69 \%$ yield increase in the Blue Basin and a $125 \%$ yield increase in the Atbara Basin. With effectively the same increase in annual precipitation, but about $1^{\circ} \mathrm{C}$ lower annual temperature and shifting of the rainfall pattern by 1 mo, the difference in yield between the 2 scenarios is $36 \mathrm{MCM}$, or $56 \%$ of historic yield of the basin.

(4) The GFDL scenario predicts a $77 \%$ decrease in Nile flow at Aswan due a temperature increase in the Blue and Atbara Basins (Fig. 3). The precipitation in both basins is $96 \%$ of historic levels, resulting in a $40 \%$ difference for the Blue Basin between GISS and GFDL and a 52\% difference for the Atbara Basin. This change in precipitation results in a $98 \mathrm{MCM}$, or $153 \%$ of historic yield, difference in yield from the basins. Gleick (1991) found similar results in a study of climate impacts on the hydrologic sensitivity of the Nile Basin.

Table 2. Nile River flows under sensitivity analysis

\begin{tabular}{lccccccccc|}
\hline $\begin{array}{l}\text { Precipitation } \\
\text { Temperature }\end{array}$ & -20 & -20 & -20 & 0 & 0 & +20 & +20 & +20 \\
& 0 & 2 & 4 & 2 & 4 & 0 & 2 & 4 \\
\hline Flow (MCM) & 32 & 10 & 2 & 39 & 8 & 147 & 87 & 27 \\
\% of base & 37 & 12 & 2 & 46 & 10 & 171 & 101 & 32 \\
abasin-wide average, change as percentage of base \\
basin-wide average, $\Delta T\left({ }^{\circ} \mathrm{C}\right)$ over base
\end{tabular}


Table 3. Nile River management results in physical units. Allocation of discharge change: GFDL-A, $100 \%$ to Sudan; GFDL-B, 50/50; and GFDL-C, $100 \%$ to Egypt

\begin{tabular}{|lccccrrr|}
\hline Scenario & $\begin{array}{c}\text { Nile } \\
\text { yield } \\
\text { (MCM) }\end{array}$ & $\begin{array}{c}\text { Sudan } \\
\text { yield } \\
\text { (MCM) }\end{array}$ & $\begin{array}{c}\text { Egypt } \\
\text { yield } \\
\text { (MCM) }\end{array}$ & $\begin{array}{c}\text { Evaporation } \\
\text { (MCM) }\end{array}$ & $\begin{array}{r}\text { Power } \\
\text { (MW) }\end{array}$ & $\begin{array}{r}\text { Energy } \\
\text { (GWh) }\end{array}$ \\
\hline Base & 84 & 19 & 55 & 9 & 1248 & 10927 \\
UKMO & 74 & 12 & 49 & 15 & 991 & 8682 \\
GISS & 109 & 30 & 65 & 14 & 1594 & 13867 \\
GFDL-A & 19 & 19 & 0 & 0 & 0 & 0 \\
GFDL-B & 19 & 0 & 12 & 7 & 70 & 618 \\
GFDL-C & 19 & 7 & 9 & 4 & 52 & 459 \\
\hline
\end{tabular}

\section{Adaptive management of Nile water resources}

Analysis of climate change impacts on the management of the Nile water resources was undertaken using a monthly river basin simulation model for Lake Nasser and Lake Aswan. The system models Sudan's abstraction as a single, lumped withdrawal upstream of inflow to Lake Nasser. The reservoir model includes evaporation and seepage losses and models the hydropower stations at Lake Nasser and Lake Aswan separately.

The model utilizes Monte-Carlo simulation applied to multi-year time-series of monthly streamflow and records the performance of the system for each month (Piper et al. 1986). The system performance is then reported in statistical values. However, these statistics are generated directly from the time-series of system performance, thus accounting for the non-linear nature of the Nile River management system. The Nile exhibits both clusters of wet and dry years and longterm alterations of wet and dry periods. The hydrology greatly influences the management strategies employed, and the natural variability must be considered in properly analyzing the impacts of climate change on management.

The mean annual flows at Aswan for each scenario were translated into input to the management model by creating a new time-series for each GCM. Each value in the base time-series (1900-1973) was multiplied by the ratio of the annual mean of the GCM to that of the base scenario. These $74 \mathrm{yr}$ time-series were then input to the model and system performance was recorded, as illustrated in Tables $3 \& 4$

Two important issues must be taken into account when interpreting these new performance statistics. First, there currently exists an agreement between Egypt and Sudan on the allocation of Nile River flows. This allocation is based on the current mean annual flow at Aswan of $84 \mathrm{MCM}$, taking into account losses, evaporation, and seepage caused by storing the water in Lake Nasser. Formal procedures also exist to deal with any increases to the Nile flow due to the planned Upper Nile development projects, which call for an equal sharing between Sudan and Egypt of any flow above the current $84 \mathrm{MCM}$. In terms of the GISS scenario, which projects a $30 \%$ increase in Nile flow, Sudan and Egypt each would receive $11.5 \mathrm{MCM}$ in additional allowable annual withdrawals after accounting for the increased evaporation due to warming over the reservoir. Allocation in cases of decreased flow at Aswan, as projected by the UKMO and GFDL scenarios, is less easily assessed. We assumed a response similar to the case of surplus: the loss (including losses from the reservoir) would be shared equally.

Second, adaptive modifications to the engineering system are likely in response to climate change. The GFDL projected decline is so great that the infrastructure would fail as the reservoir levels fall below the current outlet works threshold. Thus we examined a new engineering system: tunnels would be dug at the base of the High Aswan Dam to allow for releases. This would take the Lake Nasser Power Plant out of operation; however, the power plant at the smaller Aswan Dam would remain in operation.

In addition, under the shared-losses concept, $20 \%$ of the already low flow would be lost to evaporation. Two additional allocation scenarios were examined: GFDL$A$, in which all water goes to the Sudan before reaching Lake Nasser; and GFDL-C, where the Sudan would forego any Nile River water and all water would go to Egypt. GFDL-A would not require modifying the High Aswan Dam and GFDL-C would take advantage of the smaller crop-production scenarios and reduced irrigation needs.

Table 4. Nile River management results as a percentage of base scenario. Allocation of discharge change: GFDL-A $100 \%$ to Sudan, GFDL-B 50/50, and GFDL-C $100 \%$ to Egypt

\begin{tabular}{|lrrrrrr|}
\hline Scenario & $\begin{array}{c}\text { Nile } \\
\text { yield }\end{array}$ & $\begin{array}{c}\text { Sudan } \\
\text { yield }\end{array}$ & $\begin{array}{c}\text { Egypt } \\
\text { yield }\end{array}$ & Evaporation & Power & Energy \\
\hline Base & 100 & 100 & 100 & 100 & 100 & 100 \\
UKMO & 88 & 65 & 87 & 164 & 79 & 79 \\
GISS & 130 & 162 & 118 & 159 & 128 & 127 \\
GFDL-A & 23 & 103 & 0 & 0 & 0 & 0 \\
GFDL-B & 23 & 0 & 22 & 78 & 6 & 6 \\
GFDL-C & 23 & 38 & 17 & 44 & 4 & 4 \\
\hline
\end{tabular}


The High Aswan Dam allows both Egypt and Sudan to fully capture the benefits of the $30 \%$ increase in flow of the Nile projected by the GISS scenario (Sharaf El Din et al. 1992). These benefits are a boon in both irrigation and hydropower. In the UKMO scenario, irrigation supply to Egypt is reduced by only $13 \%$. Given current irrigation practices, a $13 \%$ improvement in irrigation efficiency seems easily accomplishable through management practices, with little capital investment. Under the GFDL-A management scenario, in which Egypt forgoes its right to Nile water, the Sudan would have $103 \%$ of current water.

Future temperature increases over Lake Nasser may greatly increase potential evaporation from the reservoir surface. This increase amplifies the effects of reduced Nile flows. The 12\% UKMO flow reduction translates into a $35 \%$ reduction in irrigation supply for the Sudan and a $13 \%$ reduction in Egyptian irrigation supply. Egyptian hydropower production is reduced by $21 \%$. Finally, the GFDL scenario offers a potential crisis for water management in Egypt and Sudan under the GFDL-B and GFDL-C allocation alternatives. Generally, water managers assert that Egypt could adapt quite easily to a 10 to $15 \%$ reduction in Nile flows (Conway \& Hulme 1993). A reduction of $20 \%$ or greater was deemed disastrous and likely to result in major social and economic impacts.

Any calculation of climate change impacts in the Nile is complicated by assumptions about intricate water allocation and institutional arrangements, chiefly between Sudan and Egypt. Sudan is assumed in the base scenario analyses to be taking its full legal 18.5 MCM allocation. It now takes only $60 \%$, but Sudanese water planning calls for it to take the full allowable diversion sometime in the future by developing more irrigation systems. This would require significant development, the feasibility of which is unclear.

Nile River water allocation might be adjusted under climate change conditions (Lema 1989). We assume that Sudan and Egypt share any shortage in the runoff scenarios presented above, though this calculation is complicated by Lake Nasser evaporation requirements. For example, UKMO scenarios gives $12 \%$ inflow decline, which translates into a $35 \%$ decrease for Sudan and 13\% for Egypt, because of Lake Nasser management, institutional structure, and increased lake evaporation (64\%). GISS gives a $30 \%$ increase in inflows to Aswan, which translates (given a $59 \%$ evaporation increase) into a $62 \%$ increase in Sudanese yield - assuming the nations share future increases and $18 \%$ to Egypt. Thus, Egypt does not fare as well given existing water use agreements

The greatest water flow adjustments would be needed under the GFDL scenario, which projects a $77 \%$ decrease in Aswan inflows. This is obviously so drastic that the water management institutions, and some of the infrastructure, would simply fail (Gleick 1992). One option is to give all the water to Sudan, thus wasting less water in Lake Nasser evaporation; under this option at least one country benefits. But this case is unlikely to appeal to Egypt. Alternatively, Sudan might take no water, allowing it to pass through, and Aswan Dam outlet works could be modified so that Egypt would get $22 \%$ of its current Aswan yield. The third case might be a $50 / 50$ split, in which Sudan would get $38 \%$ and Egypt $17 \%$ of current water. This option might be the likeliest response.

A major decline in Nile flow would probably mean that past water use agreements would change. One potential adjustment then is a renegotiation such that Sudan would not build further works to take its full share of the current supply (Iskandar 1989). Indeed, Sudan would require substantial external investment to change water management policies and practices.

There is potential for infrastructural change in the upper basin (Sudan and Ethiopia) that could mitigate some of the effects of the negative climate change scenarios. Most obvious is completion of the Jonglei Canal project (which is now over half complete). The logic of the canal depends on the fact that half of the discharge of the Equatorial Lakes now spills into the Sudd swamps and is evaporated. The goal of the canal is to circumvent the Sudd, thus shunting water around this large evaporator, and, in the process, allowing an additional irrigation area. The canal might help little under the 2 dry scenarios (UKMO and GFDL), because the Equatorial Lakes become a closed basin and little or no flow spills into the Sudd, thus negating the original engineering logic of Jonglei. However, in a case less drastic than GFDL, the canal might still reduce the overall loss of runoff due to precipitation and temperature changes. Note that GFDL presents an extreme event because under this scenario Blue Nile flow decreases and the White Nile ceases to flow. The other scenarios give increased precipitation and runoff in the Blue Nile, but there are few engineering options to take advantage of increased flow from the Blue Nile, especially in Ethiopia, in any way that increases inflows to Aswan.

The proposed Sudd collector canal system may provide some additional water under the dry scenarios. Its overall goal is to keep water out of the Sudd as much as possible, but it requires significant engineering works which have been difficult to plan and implement in the region.

Changes in management of the lower basin (Lake Nasser) and the associated irrigation system are possible in response to climate change. GISS and UKMO probably mean little change as the Lake Nasser operation can adjust to reduce these impacts (e.g. the 
adjusted UKMO loss is $13 \%$ ). Of course, such adjustments then cascade into the irrigation system. However, the UKMO scenarios might also need some adjustment to the outlet works to accept low flows.

The GFDL scenario climate change impacts do not offer feasible and readily imagined adjustments. The scenario would require physically moving the outlet works and drastically changing the seasonal cropping pattern in the irrigation system, perhaps allowing concentrated releases to better fight evaporation loss. UKMO and GFDL also cause losses in hydropower, most likely eliciting construction of run-of-river, lowhead downstream hydropower barrages (which are already being discussed in water planning). There would be more pressure for thermal power generation. Other adaptation options include increased irrigation efficiency through canal linings and better management, more reuse of drainage water, better use of the Nile valley aquifer, changes in crop types, development of western desert groundwater resources, and desalinization.

\section{DISCUSSION AND CONCLUSIONS}

This study has shown that Nile River flows throughout the basin are extremely sensitive to temperature and precipitation changes (Gleick 1992). GCM scenarios for $2 \times \mathrm{CO}_{2}$ provide widely diverging pictures of possible future river flows, from a $30 \%$ increase to a $77 \%$ decrease. Faced with such diverse scenarios, it is difficult for current water managers in the basins to adopt a response policy (Conway \& Hulme 1993).

Due to the pressures of increased population and economic growth, capital investment projects to increase water supply from the Sudd are under serious consideration (Chan \& Eagleson 1980). The results from this study might suggest that capital investment be made in decreasing water demand via more efficient irrigation management, which is one response to climate change, rather than investing in projects that may become ineffective as a result of climate change.

The possible impacts of climate change on the water budget in Egypt are governed by rainfall patterns in the Nile Basin countries, rainfall patterns on the coastal area of Egypt, evaporation rates from open water bodies and wetlands, and evaporative demand of crops (Shahin 1985). It is possible that water quality may be affected as well; it may deteriorate due to excessive evaporation from free water surfaces and seawater intrusion into shallow groundwater aquifers and drainage canals in the coastal area. Loss of fertile arable land might also take place, due to inundation and waterlogging.

\section{LITERATURE CITED}

Chan S, Eagleson P (1980) Water balance of the Bahr El Ghazel swamps. Technical Report No. 261 Ralph M Parsons Laboratory, MlT, Cambridge

Conway D. Hulme M (1993) Recent fluctuations in precipitation and runoff over the Nile sub-basins and their impact on main Nile discharge. Clim Change 25:127-151

Gleick PH (1987) The development and testing of a water balance model for climate impact assessment: modeling the Sacramento Basin. Wat Resour Res 23(6):1049-1061

Gleick PH (1991) The vulnerability of runoff in the Nile Basin to climate changes. Environ Prof 13:66-73

Gleick PH (1992) Vulnerability of runoff in the Nile Basin to climatic changes. In: Abu Zeid MA, Biswas AK (eds) Climatic fluctuations and water management. ButterworthHeinemann, p 125-128

Hansen J, Russell G, Rind D, Stone P, Lacis A, Lebedoff S, Ruedy R, Travis L (1983) Efficient three-dimensional global models for climate studies: models I and II. Mon Weather Rev 111:609-662

Hulme $M$ (1992) Recent and future precipitation changes over the Nile Basin. In: Abu Zeid MA, Biswas AK (eds) Climatic fluctuations and water management. Butterworth-Heinemann, $p 187-201$

Iskandar l (1989) Drought and management of water resources in the Sudan. Paper presented at the International Seminar on Climatic Fluctuations and Water Management, 11-14 December 1989, Cairo, Egypt

Kalinin GP (1971) Global hydrology. US Dept of Commerce, NTIS, Springfield (translated from Russian, Israel Program for Scientific Translation Ltd)

Lema AJ (1989) East African climate over the last one hundred years (1880-1980). Paper presented at the International Seminar on Climatic Fluctuations and Water Management, 11-14 December 1989, Cairo, Egypt

Manabe S, Wetherald RT (1987) Large-scale changes in soil wetness induced by an increase in carbon dioxide $\mathrm{J}$ Atmos Sci 44:1211-1235

Mitchell JFB, Senior CA, Ingram WJ (1989) $\mathrm{CO}_{2}$ and climate. a missing feedback. Nature 341:132-134

Oliver J (1969) Problems of determining evapotranspiration in the semi-arid tropics illustrated with reference to the Sudan. J Trop Geogr 29(1):64-74

Piper BS, Plinston DT, Sutcliffe JV (1986) The water balance of Lake Victoria. Hydrol Sci J 31:25-37

Sestini G (1993) Implications of climatic changes for the Nile Delta. In: Sestini G (ed) Climatic change in the Mediterranean. E. Arnold Publisher, London, p 535-601

Shahin M (1985) Hydrology of the Nile Basin. Elsevier Science Publishing Company, New York

Sharaf El Din SH, Khafagy AA, Mahar AM (1992) The hydrological and meteorological factors controlling flood forecasting. In: Abu Zeid MA, Biswas AK (eds) Climatic fluctuations and water management. Butterworth-Heinemann, p 59-70

Shaw E (1987) Practical hydrology. J Wiley, London

Sutcliffe JV, Parks YP (1987) Water balance of the Sudd and Jonglei Canal. Hydrol Sci J 32:143-159

Unganai LS (1996) Historic and future climatic change in Zimbabwe. Clim Res 6:137-145

Wigley TML (1993) Future climate of the Mediterranean Basin with particular emphasis on changes in precipitation. In: Sestini $G$ (ed) Climatic change in the Mediterranean. E. Arnold Publisher, London, p 15-44

WMO (1977) Hydrologic model of the Upper Nile Basin, Vol 1-B, Appendices. World Meteorological Organization, Geneva 